\title{
WHY ORIGINALISM NEEDS CRITICAL THEORY: DEMOCRACY, LANGUAGE, AND SOCIAL POWER
}

\author{
Annaleigh E. Curtis*
}

TABle of Contents

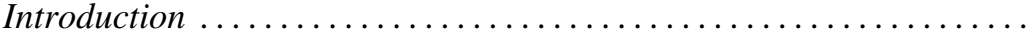

I. Two Tenets of Originalism........................ 441

A. Text as Democratic Expression .................. 441

B. The Social Contingency of Meaning............... 442

II. An Old Problem for Originalism: Social Exclusion........ 443

III. A New Problem for Originalism: Hermeneutical Exclusion ....................................

A. Hermeneutical Injustice and the Structure of

Language ..................................

B. Exclusionary Process ............................ 449

C. Exclusionary Substance ....................... 451
\end{abstract}

IV. Critical Theory as a Necessary Corrective ............. 454

Conclusion ....................................... 459

\section{INTRODUCTION}

Originalism $^{1}$ is not a monolith. I take it here to refer to a theory of statutory interpretation that requires adherence to the statute's original public meaning - what people at the time would have understood it to mean. ${ }^{2}$ One purpose of this method of interpretation is the preservation of democratic

* J.D. Candidate, Harvard Law School, 2016; Ph.D., Philosophy, University of Colorado Boulder, 2013; Graduate Certificate, Women and Gender Studies, University of Colorado Boulder, 2013; B.A., Philosophy, Washburn University, 2008. I would like to thank Dean Martha Minow and Professor Mark Tushnet for their helpful comments. I would also like to thank the Harvard Journal of Law \& Gender for their work providing both excellent substantive suggestions and editorial prowess. Finally, I thank Alison Jaggar, who helped me in my earlier dissertation work to develop some of the ideas that are found in this Note.

${ }^{1}$ Though I refer to the view outlined by this name throughout, it is sometimes called textualism. See generally, e.g., John F. Manning, What Divides Textualists from Purposivists?, 106 Colum. L. REv. 70 (2006) (referring to the theory of originalism that I address in this Note as "textualism"). I have picked this term to provide consistency throughout, despite the different terms used in the literature to which I cite.

${ }^{2}$ See, e.g., Ingrid Wuerth, An Originalism for Foreign Affairs?, 53 St. LouIs U. L.J. 5,8 (2008) ("'Originalism,' as used here, means the interpretation of the Constitution in accordance with the original public meaning of the text, unless that meaning cannot be determined with sufficient confidence."); Gary Lawson \& Guy Seidman, Originalism as a Legal Enterprise, 23 Const. Comment. 47, 48 (2006); Manning, supra note 1, at 77; Antonin Scalia, Originalism: the Lesser Evil, 57 U. Cin. L. Rev. 849, 851-52 (1989) (discussing the method of interpretation used in Myers v. United States, 272 U.S. 52 (1926)) [hereinafter Scalia, Lesser]. 
impulses; failing to interpret the text of a law as it was understood by those who adopted it is to impose judicial will, to override the result of the political process on the whim of one or a few individuals. ${ }^{3}$ As a result, for originalists, determining this original meaning, or a semantically permissible range of meaning, is the primary task of statutory interpretation. ${ }^{4}$ In the context of constitutional interpretation, in particular, originalists face a cluster of criticisms that might best be summed up as the charge that the original meaning of the Constitution is exclusionary in some way. ${ }^{5}$ One example of this sort of criticism that has received especially fervent attention is the charge that originalism is incapable of accommodating the result in Brown $v$. Board of Education. ${ }^{6}$ The drafters of the Fourteenth Amendment would never have understood it to require desegregation, ${ }^{7}$ the argument goes, yet desegregation was clearly the required outcome in the case, so originalism must be defective, and gravely so. ${ }^{8}$

${ }^{3}$ See William N. Eskridge, Jr., The New Textualism, 37 UCLA L. Rev. 621, 671-77 (1990) (reconstructing the argument in this way: "In a representative democracy . . . major policy decisions should be made by the popularly elected branches of government, mainly Congress. Unelected judges should make as few policy choices as possible, especially when interpreting statutes."). Compare Antonin Scalia, Common-Law Courts in a Civil-Law System: The Role of United States Federal Courts in Interpreting the Constitution and Laws, in A Matter of Interpretation: Federal Courts ANd the Law 3, 17-18 (Amy Gutmann ed., 1997) [hereinafter Scalia, Common-Law] ("[U]nder the guise or even the self-delusion of pursuing unexpressed legislative intents, common-law judges will in fact pursue their own objectives and desires, extending their lawmaking proclivities from the common law to the statutory field.") with Scalia, Lesser, supra note 2 , at 862 ("[O]riginalism seems to me more compatible with the nature and purpose of a Constitution in a democratic system. A democratic society does not, by and large, need constitutional guarantees to insure that its laws will reflect 'current values.' Elections take care of that quite well. The purpose of constitutional guarantees . . . is precisely to prevent the law from reflecting certain changes in original values that the society adopting the Constitution thinks fundamentally undesirable. Or, more precisely, to require the society to devote to the subject the long and hard consideration required for a constitutional amendment before those particular values can be cast aside.") (emphasis omitted).

${ }^{4}$ See, e.g., Scalia, Common-Law, supra note 3, at 22-24 ("Words do have a limited range of meaning, and no interpretation that goes beyond that range is permissible.").

${ }^{5}$ Here, I have in mind criticisms that the drafters, or the ordinary politically active person at the time, would not have included, e.g., women or racial minorities in their contemplation of the rights they laid down in text. Also relevant are criticisms that they would not have included specific activities, like desegregation of schools or pay discrimination.

${ }^{6} 347$ U.S. 483 (1954) (requiring the desegregation of schools under the Fourteenth Amendment).

${ }^{7}$ See, e.g., Robert H. Bork, The Tempting of America 75-76 (1990); Michael Klarman, An Interpretive History of Modern Equal Protection, 90 MicH. L. Rev. 213, 252 (1991); Mark V. Tushnet, Following the Rules Laid Down: A Critique of Interpretivism and Neutral Principles, 96 Harv. L. Rev. 781, 800 (1983). But see, e.g., Charles A. Lofgren, The Plessy Case 65 (1987); Michael Perry, The Constitution in the Courts 145-46 (1994); John Harrison, Reconstructing the Privileges or Immunities Clause, 101 Yale L.J. 1385, 1462-63 (1992); Michael W. McConnell, Originalism and the Desegregation Decisions, 81 VA. L. Rev. 947, 953 (1995).

${ }^{8}$ See Mark A. Graber, Dred Scott and the Problem of Constitutional Evil 15 (2006) ("Contemporary constitutional theory rests on three premises: Brown v. Board 
This Note does not take a stance on the lively debate over this question. Rather, I wish to suggest here that there is a more potent version of the criticism that originalism is exclusionary and ultimately undemocratic. Meaning is not given; it is made. In particular, language takes on meaning only in the context of a society, ${ }^{9}$ it changes over time, and it reflects the social structures in society, for good or ill. In a society marked by hierarchy_race-based, gender-based, class-based, and otherwise-language, too, is marked by hierarchy..$^{10}$ One way in which this manifests itself is through hermeneutical injustices: gaps in collective conceptual resources where social experiences go unnamed. ${ }^{11}$ Think, for example, of the gap in collective understanding of sexual harassment prior to the creation of the concept. ${ }^{12}$

So much of the debate over originalism and its merits has focused on determining the meaning of the text, that commentators have overlooked the potential problems with that meaning in itself, whatever it turns out to be. Suppose, for the sake of argument, that we can determine the original meaning of some bit of text. Our language at any given time provides a snapshot, not merely of what is meant by some string of words, but of who is in power, who is left out, and what is thought to be important. Uncovering the meaning of a statute written in a language that is itself undemocratic, then, is no help to originalists if they take seriously their own commitment to democracy. To put this another way, the semantic context of the words that end up in statutes and constitutions is not politically neutral, so a theory like originalism that relies on semantic context for interpretation will not be politically neutral either. This Note presents a problem for originalism's semantic theory as applied to its political theory instead of the other way round.

of Education was correct, Lochner v. New York was wrong, and Dred Scott v. Sandford was wrong.").

9 See Manning, supra note 1, at 79 ("[Textualists] assert that language is intelligible only by virtue of a community's shared conventions for understanding words in context."); see also Scalia, Common-Law, supra note 3, at 37 ("In textual interpretation, context is everything, and the context of the Constitution tells us not to expect nit-picking detail, and to give words and phrases an expansive rather than narrow interpretationthough not an interpretation that language will not bear.").

${ }^{10}$ See, e.g., Jennifer Hornsby, Feminism in Philosophy of Language, in The CAMBRidge Companion to Feminism in Philosophy 78, 78 (Miranda Fricker \& Jennifer Hornsby eds., 2000); see also Alison M. Jaggar, Feminism in Ethics: Moral Justification, in The Cambridge Companion to Feminism in Philosophy, supra, at 225, 238 ("Speaking requires a language but dominant vocabularies may lack the resources necessary to express the perspectives of subordinated groups.").

${ }^{11}$ Miranda Fricker, Epistemic InJustice 151 (2007); see also, e.g., Iris Marian Young, InClusion AND Democracy 55 (2000) ("Having obtained a presence in the public, citizens sometimes find that those still more powerful in the process exercise, often unconsciously, a new form of exclusion: others ignore or dismiss or patronize their statements and expressions. Though formally included in a forum or process, people may find that their claims are not taken seriously ... . I call these familiar experiences internal exclusion, because they concern ways that people lack effective opportunity to influence the thinking of others even when they have access to fora and procedures of decisionmaking.").

${ }^{12}$ Fricker, supra note 11 , at 150. 
I argue here that the existence of hermeneutical injustice as a pervasive feature of our collective linguistic and conceptual resources undermines the originalist task at two levels: one procedural, one substantive. First, large portions of society were (and continue to be) systematically excluded from the process of meaning creation when the Constitution and its Amendments were adopted, so originalism relies on enforcement of a meaning that was generated through an undemocratic process. Second, the original meaning of some ${ }^{13}$ words in those texts may be substantively objectionable as a result because they fail to capture the relevant experiences of affected people at the time even if they accurately capture the conceptual understanding of reasonable people at the time, and this substantive failing may infect the text's democratic legitimacy. To the extent that it can be overcome, overcoming this epistemic problem will require originalists to take seriously the insights of critical theory, understood in this Note as a normative inquiry into the historical context of the language and meaning of statutory text. ${ }^{14}$ Because originalists are already committed to a nominally descriptive inquiry into this context, and because this nominally descriptive inquiry masks the inherently normative aspects of the hermeneutical landscape, the switch to an explicitly normative inquiry may prove quite painless. ${ }^{15}$

${ }^{13}$ I want to remain agnostic in this Note about whether the problems I present might reach all the concepts employed in the Constitution (or any other law). It is possible that they do, but that is a broad, strong claim that would require further defense. For the purposes of this piece, I just suppose that at least some of the concepts employed require some critical analysis to avoid causing problems. As a rough first pass, we can expect the problems I describe here to arise primarily in cases where concepts have some normative content already built into them. For example, "Person" carries a sort of normative baggage that "Age of thirty five Years," U.S. Const. art. II, § 1, cl. 5, does not.

${ }^{14}$ See, e.g., Iris Marion Young, Justice and the Politics of Difference 5 (2011 ed. 2011) ("[C]ritical theory is a normative reflection that is historically and socially contextualized. Critical theory rejects as illusory the effort to construct a universal normative system insulated from a particular society. Normative reflection must begin from historically specific circumstances because there is nothing but what is, the given, the situated interest in justice, from which to start. . . . Social description and explanation must be critical, that is, aim to evaluate the given in normative terms. Without such a critical stance, many questions about what occurs in a society and why, who benefits and who is harmed, will not be asked, and social theory is liable to reaffirm and reify the given social reality.").

${ }^{15}$ At least, theoretically painless. Practically, one imagines such a switch would be difficult given the existing but contingent political valences of originalism on the one hand and various sorts of critical theory on the other. Compare Margaret H. Lemos, The Politics of Statutory Interpretation, 89 Notre Dame L. Rev. 849, 853 (2013) (arguing that textualism has been historically associated with political conservatism) with Mark Tushnet, Critical Legal Studies: A Political History, 100 Yale L.J. 1515, 1516 (1991) (suggesting that "critical legal studies is a political location for a group of people on the Left who share the project of supporting and extending the domain of the Left in the legal academy"). 


\section{Two Tenets of Originalism}

Law is so much about what words mean, whether the words of a contract, a statute, a policy document, or a protection order. In each case, the meaning of those words is important because they will bind, enable, constrain, punish, or shield the people to whom they apply, and different interpretations will benefit and burden different parties. In the following Parts, I argue that originalism about statutory and constitutional interpretation is driven by two connected intuitions about using words to bind actions: people should be bound only by those words as collectively understood at the time of enactment, and words do not have meanings beyond how they are used in particular social contexts. I briefly discuss each of these tenets of originalism in turn.

\section{A. Text as Democratic Expression}

If you ask me if I want anything from Starbucks, and I ask you to get me a tall soy latte, what I mean is that I want a tall soy latte. If you come back with a grande soy latte, or a tall cow's milk latte, or a tall soy mocha, then there is a problem because none of those things is what I requested. If we draft a contract together whereby you agree to bring me a tall soy latte every day in exchange for a fee, but you bring me one of the other things, then you have breached the contract precisely because none of those things is what I requested. We want others to understand what we mean when we express ideas, and when people subvert our clear meaning, it is upsetting.

The originalist invites us to extend this logic to the democratic legislative process. ${ }^{16}$ That is, laws are drafted in order to accomplish certain goals. In an attempt to realize these goals, legislators use some words and phrases instead of others. If a legislature wants to regulate air quality, they will write a statute that discusses air quality, not food safety or immigration restrictions. Even if a law is drafted carelessly, the fact that it was passed democratically provides all the reason needed to enforce it as written, just as there is reason to bring me a tall soy latte even if you think I misspoke and would prefer a grande.

If legislatures (or the drafters of the Constitution) speak clearly, then judicial failure to enforce the clear meaning of the text amounts to subversion of the autonomy of the drafters. In this case, however, the will and sense of autonomy at stake is the will of the people as a whole (who theoretically authorize the drafters to make law), which makes the subversion one of democracy and all the more grave. A judge or group of judges has no author-

${ }^{16}$ See infra Part II for a discussion of how the Constitution and many statutes were created through a process which was, in fact, not democratically representative, and how this lack of representativeness may call into question the legitimate basis for the originalist interpretive theory. 
ity to interpret laws in a way inconsistent with the public meaning. Expounding this point, Justice Scalia writes:

[I]t is simply incompatible with democratic government, or indeed, even with fair government, to have the meaning of a law determined by what the lawgiver meant, rather than by what the lawgiver promulgated. . . It is the law that governs, not the intent of the lawgiver. That seems to me the essence of the famous American ideal set forth in the Massachusetts constitution: A government of laws, not of men. Men may intend what they will; but it is only the laws that they enact which bind us. ${ }^{17}$

Judge Bork, on the same point, writes that "the elected legislator or executive may act where not forbidden; his delegation of power from the people through an election is his authority. But the judge may act only where authorized[;] . . . his commission is to apply the law." ${ }^{18}$ As Professor Manning has noted, then, the originalist holds fast to the text precisely because it alone "has survived the constitutionally prescribed process of bicameralism and presentment." 19

\section{B. The Social Contingency of Meaning}

A second tenet of originalism, which is in some ways a recent development or expression of the view, is that the meaning of words and phrases is socially contingent. ${ }^{20}$ That is, meaning is not given or eternal. It changes over time based on the context. ${ }^{21}$ As Justice Scalia writes, "the meaning of a word cannot be determined in isolation, but must be drawn from the context in which it is used." 22 Though this fact is obvious enough, it is made explicit in an originalist interpretive theory because it helps to explain why and how words acquire meaning in the first place, and how they might mean different things at different times or to different speakers and groups. "[L]anguage is intelligible only by virtue of a community's shared conventions for under-

${ }^{17}$ Scalia, Common-Law, supra note 3, at 17 (emphasis omitted).

${ }^{18}$ Bork, supra note 7, at 150. See also Gregory Bassham, Original InTEnT AND the Constitution: A Philosophical Study 92-94 (1992) (noting that the appeal of originalism comes from notions of delegation and legitimate separation of power rather than majority rule).

${ }^{19}$ Manning, supra note 1, at 73; accord Jonathan Molot, The Rise and Fall of Textualism, 106 Colum. L. Rev. 1, 27 (2006).

${ }^{20}$ This growing recognition begins with Justice Scalia's "new textualism" and is refined by Manning's expressions of textualism. Eskridge, supra note 3 at 623; Manning, supra note 1, at 73-75. See generally Lawrence B. Solum, Semantic Originalism 30 (Ill. Pub. Law \& Legal Theory Research Paper Series, Research Paper No. 07-24, 2008) [hereinafter Solum, Semantic], archived at http://perma.cc/T58E-WRXB (arguing for the importance of the fixation thesis - the thesis that the semantic content of a law is fixed at the time it is passed-to all originalist theories whether for semantic or policy reasons).

${ }^{21}$ See, e.g., Manning, supra note 1, at 75 ("the meaning of statutory language (like all language) depends wholly on context").

${ }^{22}$ Deal v. United States, 508 U.S. 129, 132 (1993). 
standing words in context." ${ }^{23}$ Manning gives voice to this point with characteristic lucidity:

Because the meaning of language depends on the way a linguistic community uses words and phrases in context, textualists recognize that meaning can never be found exclusively within the enacted text. This feature of textualism, moreover, goes well beyond the often subconscious process of reading words in context in order to pinpoint the "ordinary" meaning of a word that may mean several things in common parlance. ${ }^{24}$

Manning goes on to note the importance of various cues in interpreting language, from the use of terms of art, to traditional canons of construction, to the role of purpose in shaping linguistic choices. ${ }^{25}$ While a purposivist will use these tools as well, she will also turn to the policy context- "the overall tenor of the statute, patterns of policy judgments made in related legislation, the 'evil' that inspired Congress to act, or express statements found in the legislative history"26 — of a law for guidance in its interpretation. Ultimately, Manning argues convincingly that what separates originalists from purposivists is which context they consider most relevant: the semantic context, rather than the policy context. ${ }^{27}$

The particular semantic contextual cues matter precisely because meaning is not static and getting the meaning correct matters. Later, in Part III.A, I take this analysis a bit further to argue that any semantic context carries with it the marks of oppression and inequality within a society.

\section{An Old Problem for Originalism: Social Exclusion}

Perhaps the most ready, well-worn objection to originalism is that it has necessarily failed to keep pace with a society that has progressed beyond various forms of inequality and exclusion..$^{28}$ It demands the enforcement of meanings that we would consider unacceptable today. Cass Sunstein put the problem this way:

${ }^{23}$ Manning, supra note 1, at 79.

${ }^{24} I d$. at 78 .

${ }^{25} \mathrm{Id}$. at $81-85$.

${ }^{26} I d$. at 71 .

${ }^{27} \mathrm{Id}$. at 110 .

${ }^{28}$ An objection, it should be noted, which is not unique to originalism. "The American experience with slavery demonstrates how, in the wrong hands or in the wrong circumstances, all constitutional theories yield unjust conclusions. [Chief Justice] Taney [writing the majority decision in Dred Scott v. Sandford, 60 U.S. 393, 419 (1856), could employ numerous constitutional modalities to promote proslavery and racist policies because all forms of constitutional logic are capable of yielding evil results." GRABER, supra note 8 , at 83 . 
Hard originalism ${ }^{29}$ is an unacceptable project because it is inconsistent with too much that is both settled and worthy in many areas, including free speech, religious liberty, racial discrimination, and sex discrimination. The problem with hard originalism-putting the epistemological problems to one side-is not that it is indeterminate, but that it would result in an unacceptably narrow set of liberties for the United States in the Twentieth Century. ${ }^{30}$

It is an unfortunate fact of history that the laws we have-particularly, but not exclusively, the older they are-were written by, and to serve, certain groups of people and not others. The Constitution was written at a time when slavery was part of the basic economic structure of the country, by many people who themselves held slaves, and it explicitly preserved the institution of slavery. ${ }^{31}$ Similarly, women, poor white men, and other whole classes of people were not included in the ratification process or contemplated directly by the document that resulted..$^{32}$ Yet today we purport to have advanced, and among these advancements are the inclusion of racial minorities, women, and the poor in the ambit of public life. Of course, the Constitution has been amended several times since the founding of the country, and several of these amendments are corrective of original exclusions. Yet the same problems remain, though in a different way. In a country that ostensibly progresses gradually toward greater inclusion and recognition of rights, old laws will reflect old consensus and fail to be inclusive.

This is a problem for originalism, but not (or not only) because it leads to unacceptable conclusions about current cases. This apparent problem can be dealt with somewhat glibly by the originalist, who may just point to the democratic process. If it is true that a law passed in the past no longer reflects the will of the people in the present, then those people can change the law, even amend the Constitution, or pass a new law that does. Until that happens, the only thing a judge is authorized to do is enforce the law as written. ${ }^{33}$ It is not uncommon to see courts do just this: enforce an unsavory interpretation, note that they find it unsavory, and suggest that the legislature

${ }^{29}$ Sunstein distinguishes between hard and soft originalism. Hard originalists "are trying to do something like go back in a time machine and ask the Framers very specific questions about how we ought to resolve very particular problems." Cass Sunstein, Five Theses on Originalism, 19 HARv. J.L. \& Pub. Pol'y 311, 312 (1996). Of course, so put, this view is distinct from the kind of sophisticated original public meaning theory that $I$ discuss here.

${ }^{30} \mathrm{Id}$.

${ }^{31}$ See Jamal Greene, Originalism's Race Problem, 88 Denv. U. L. Rev. 517, 518-19 (2011).

${ }^{32}$ See, e.g., id. at 518. See generally Akhil Reed Amar, America's Constitution: A Biography (2005) (providing a history of the Constitution); PAuline Maier, Ratification: The People Debate the Constitution, 1787-1788 (2011) (providing a history of State ratifications of the Constitution).

${ }^{33}$ See, e.g., Bork, supra note 7, at 147. 
take action. ${ }^{34}$ Rather, social exclusion is a problem for originalism most pressingly because it undermines the chief benefit of being tied to the original meaning of the text, which is that it was that text, with that meaningand no other-that was passed democratically. If the text came to govern without the consent of a large portion of the people it purported to govern at the time and into the future, then its democratic appeal is lost. The objection is sometimes framed as a "dead hand" problem. ${ }^{35}$

Originalists may respond to this sort of criticism by denying that the original understanding is at odds with the current views or by biting the bullet and suggesting that a legislative change or constitutional amendment is required. Steven Calabresi, for example, responds to concerns about accommodating anti-discrimination laws in an originalist constitutional theory by denying that Congress has the power to pass discriminatory laws with respect to race or gender (but does with respect to sexual orientation, an outcome that may cause more discomfort today than in 2007) in the first place because they are not "necessary and proper" and constitute "Adjudication" rather than "Legislation," and by offering an alternative history of the Fourteenth Amendment on which decisions like Brown v. Board of Education $^{36}$ and Loving $v$. Virginia ${ }^{37}$ could have been correctly decided on originalist grounds. ${ }^{38}$ Similarly, Judge Bork notes that, because the Constitution sets a floor on rights, we, the people of the present, are free to expand rights:

The question is really meant to indicate that courts should be free to write into the Constitution freedoms from democratic control that the Framers omitted. Yet that is the one proposition that the objection to rule by the dead, if it had any validity, does not support. The dead, and unrepresentative, men who enacted our Bill of Rights and the Civil War amendments did not thereby forbid us, the living, to add new freedoms. We remain entirely free to create all the additional freedoms we want by constitutional amendment or by simple legislation, and the nation has done so frequently.

${ }^{34}$ See, e.g., Ledbetter v. Goodyear Tire \& Rubber Co., Inc., 550 U.S. 618, 661 (2007) (Ginsburg, J., dissenting); Commonwealth v. Robertson, 5 N.E.3d 522, 529 n.17 (Mass. 2014) (reversing a criminal conviction for taking "upskirt" photos under a "Peeping Tom" statute, but noting that other states had criminalized such photos explicitly).

${ }^{35}$ See, e.g., Greene, supra note 31, at 518. Compare Reva B. Siegel, Heller \& Originalism's Dead Hand-In Theory and Practice, 56 UCLA L. Rev. 1399, 1423-24 (2009) (arguing that the problem is merely a theoretical one) with Frank Easterbrook, Textualism and the Dead Hand, 66 Geo. WAsh. L. Rev. 1119, 1123 (1998) (arguing against the objection).

36347 U.S. 483 (1954).

37388 U.S. 1 (1967).

${ }^{38}$ Steven G. Calabresi, A Critical Introduction to the Originalism Debate, in Originalism: A Quarter-Century of Debate 1, 32-36 (Steven G. Calabresi ed., 2007). 
What the questioner is really driving at is why judges, not the electorate but judges, should be bound to protect against democratic choice only those liberties actually mentioned in the Constitution. The real objection is not to rule by dead men who were not fully representative of their society but to rule by living majorities. ${ }^{39}$

Originalists of the public meaning variety, which is the view I intend to challenge here, may also point out that even if people were systematically and tragically excluded from the democratic process when a particular statute or constitutional provision/amendment was passed, what matters is how the language would have been understood publicly at the time, which may allow historical arguments for the true meaning of the language.

\section{A New Problem for Originalism: Hermeneutical Exclusion}

The old version(s) of the exclusion objection to originalism are compelling for many people, but not if those people are originalists. ${ }^{40}$ If one finds originalism attractive as a theory, there are certainly answers to the objection as presented, and it is not unreasonable for a person to decide that the advantages of the theory make up for its problems. In this Part, I aim to tighten the vice on the originalist and make acceptance of the view in the face of the exclusion objection more painful. To do this, the objection needs to shift focus to the relationship between language and social power instead of the impact of exclusion on particular laws. The objection presented here, as a result, presents a deeper problem for originalism in that it calls its democratic legitimacy into question even in cases where a particular enactment is not obviously problematic. In short, the hermeneutical exclusion objection charges that language and its meaning are undemocratic in a society marked by inequality, and that, as a result, interpreting a law in accord with its common meaning at the time of enactment risks enforcing that undemocratic meaning on people who should not be bound by it.

\section{A. Hermeneutical Injustice and the Structure of Language}

Hermeneutical injustice is an intimidating name for a simple concept. Fricker defines a hermeneutical injustice as "a lacuna where the name of a distinctive social experience should be." ${ }^{41}$ In other words, it is a deficiency in our collective conceptual resources, reflected through language, where present ways of thinking and talking are inadequate to describe reality. This sort of gap is particularly problematic where the social experience in ques-

\footnotetext{
${ }^{39}$ Bork, supra note 7 , at 171 .

${ }^{40}$ See, e.g., Calabresi, supra note 38 , at 32-33.

${ }^{41}$ FRICKER, supra note 11 , at $150-51$.
} 
tion is oppressive or unfair because the inability to explain what the experience is or why it is bad can delay remedial action. ${ }^{42}$ Because language is ever-present in human life, it is easy to see it as natural, given, and complete, but this is manifestly not so. ${ }^{43}$ Language is made by and through social interaction. It does not neatly map onto social experience. As discussed earlier in Part I.B, originalists are well-equipped to understand this insight. The same intuition that gives force to the originalist focus on the meaning of words as understood at the time they were enacted-the intuition that meaning is socially contingent-lends plausibility to the idea of hermeneutical injustice. If meaning is socially contingent, it is because meaning depends on and reflects particular social contexts, and if these social contexts are unjust, unequal, undemocratic, then language will reflect this. This is simply a part of the semantic context of a text. If originalism is supposed to reflect common sense methods of interpreting language,,$^{44}$ then it must consider this feature of linguistic evolution.

Hermeneutical injustices often result from a collective inability to recognize and take seriously the experiences of members of oppressed groups.

Hermeneutical injustices of this sort result from obstacles and limitations in the social imaginary that produce the inability to see and hear certain things, forms of insensitivity that limit the communicative and epistemic capacities of members of certain groups and preclude a genuine understanding of their experiences, problems, and situations..$^{45}$

Because members of oppressed groups are also members of the broader social context in which language develops, they are likewise hampered in their ability to give voice to their experiences. I mentioned the example of the concept of sexual harassment earlier. Women (and other marginalized people in the workplace) experienced sexual harassment long before we were collectively able to give a name to the experience and thus able to

${ }^{42}$ See infra text accompanying notes 43-44.

${ }^{43}$ See, e.g., Sally Haslanger \& Jennifer Saul, Philosophical Analysis and Social Kinds: What Good Are Our Intuitions?, 80 Proc. Aristotelian Soc'y, Supplementary VOLUMES 89, 114 (2006) ("[O]ften what we take to be analytic principles actually encode certain social arrangements, and the relationship between terms encode certain power structures.").

${ }^{44}$ And I think that it is supposed to. See, e.g., Bork, supra note 7, at 144 ("Law is a public act. Secret reservations or intentions count for nothing. All that counts is how the words used in the Constitution would have been understood at the time. The original understanding is thus manifested in the words used and in secondary materials, such as debates at the conventions, public discussion, newspaper articles, dictionaries in use at the time, and the like. Almost no one would deny this; in fact almost everyone would find it obvious to the point of thinking it fatuous to state the matter-except in the case of the Constitution.").

45 Jose Medina, The Epistemology of Resistance: Gender and Racial Oppression, Epistemic InJustice, and Resistant Imaginations 72 (2013). 
discuss its harms and counteract it, both through law and other means. ${ }^{46}$ Without a concept to appeal to, people who are experiencing some form of objectionable behavior may find it difficult to convince themselves and those around them that anything worth addressing has taken place. Even after the concept of sexual harassment had entered the lexicon, it failed to be understood as a very serious issue. Others in the workplace attempted to explain away purported instances of harassment in a number of ways: convincing the complainant she is selfish for bringing negative attention to the organization, convincing the complainant he must have misunderstood the event, advancing a "boys will be boys" or a "harmless joke" explanation, and so on. ${ }^{47}$ In each of these cases, the explanation for the response need not (and probably should not) be that the person has ill will toward the complainant. Rather, these responses come out of an inability to fully grasp the experience of another as a result of underdeveloped conceptual resources. ${ }^{48}$

In other words, "dominant vocabularies may lack the resources necessary to express the perspectives of subordinated groups." ${ }^{49}$ Yet it is this same dominant vocabulary that makes up our semantic context. Because of this, we can expect that some of these conceptual gaps will affect how laws are written and how they are interpreted. We should expect that this will be especially salient when the laws in question are aimed at, or are presently applied to, members of oppressed groups. In the following two Parts, I discuss two ways in which originalism's failure to account for hermeneutical injustice in interpretation risks undermining its chief benefit of democratic legitimacy. First, hermeneutical injustice calls into question the process by which language develops, suggesting that it is deeply undemocratic. Second, hermeneutical injustice is likely to result in substantively undemocratic concepts being put to use in laws.

\footnotetext{
${ }^{46}$ An excerpt from Susan Brownmiller's memoir describes the moment a group of women coined the term:

The "this" they were going to break the silence about had no name. "Eight of us were sitting in an office of Human Affairs," Sauvigne remembers, "brainstorming about what we were going to write on the posters for our speak-out. We were referring to it as 'sexual intimidation,' 'sexual coercion,' 'sexual exploitation on the job.' None of those names seemed quite right. We wanted something that embraced a whole range of subtle and unsubtle persistent behaviors. Somebody come up with 'harassment.' Sexual harassment! Instantly we agreed. That's what it was."
}

Susan Brownmiller, In Our Time: Memoir of a Revolution 281 (1999).

${ }^{47}$ See Robin Patric Clair, The Use of Framing Devices to Sequester Organizational Narratives: Hegemony and Harassment, 60 Comm. Monographs 113, 118-20 (1993).

${ }^{48}$ An additional concern that is specific to the legal system may be the difficulty of explaining a wrong done to one in a way that looks like a claim the legal system is willing to deal with, particularly after Bell Atlantic Corp. v. Twombly, 550 U.S. 544 (2007), and Ashcroft v. Iqbal, 556 U.S. 662 (2009), which raised the pleading standard to require a showing of plausibility. Annaleigh E. Curtis, Epistemic Injustice in Procedural Gatekeeping: Credibility and Social Justice (Jan. 15, 2015) (unpublished manuscript) (on file with author).

${ }^{49}$ Jaggar, supra note 10, at 238. 


\section{B. Exclusionary Process}

It follows from the example of hermeneutical injustice that the necessary collectivity of language does not entail that it is democratically created. To the contrary, language develops parallel to social structures, which have been unjust. The implications for originalism are serious. Originalism, I have argued, claims legitimacy from the ideas that the language in a statute or constitutional provision means something and that this meaning should be enforced because that language, and not some other string of text, was enacted through democratic processes. The words, that is, have the people's stamp of approval. However, even if the process for passing laws is democratically legitimate, I have argued that the language itself is not. The available words and concepts do not accurately capture social reality, and this failure disproportionately affects some groups. ${ }^{50}$ As a result, we can expect the words that end up as law to be vulnerable to the same gaps and exclusions.

The history of legal interpretation tells the story itself. The majority opinion in Dred Scott v. Sandford ${ }^{51}$ engages in an originalist analysis of the words "people" and "citizen," arguing, probably accurately, that the original understanding of these words would never have included slaves in those categories..$^{52}$

The legislation of the States therefore shows, in a manner not to be mistaken, the inferior and subject condition of that race at the time the Constitution was adopted, and long afterwards, throughout the thirteen States by which that instrument was framed; and it is hardly consistent with the respect due to these States, to suppose that they regarded at that time, as fellow-citizens and members of the sovereignty, a class of beings whom they had thus stigmatized . . . . It cannot be supposed that they intended to secure to them rights, and privileges, and rank, in the new political body throughout the Union, which every one of them denied within the limits of its own dominion. ${ }^{53}$

The conclusion is difficult to escape precisely because the collective understanding of citizenship at the time of the founding was unjust and exclusionary. It was, I am suggesting, an act of conceptual domination over Black people at the time that slaves were not considered eligible for citizenship. If the linguistic and conceptual landscape at the time of the framing had been truly democratic, it likely would not have included this carve out in the concept.

${ }^{50}$ Medina, supra note 45 , at 72.

${ }^{51} 60$ U.S. 393 (1856).

${ }^{52} I d$. at 419.

${ }^{53}$ Id. at 416. But see Justice Curtis's dissent in that case for a different account of the original meaning. $I d$. at $569-71$. 
Though this example serves just as well to demonstrate the substantive problem, considered in full in the next Part, it demonstrates the procedural problem as well. Even if the original understanding of citizenship was such that the concept contemplated slaves, and even if this resulted in a different decision in Dred Scott, it should still trouble originalists that the conceptual resources of the time were not open to all for contribution. Because language is undemocratic in ways that should trouble us when it comes to legal protections and entitlements, an uncritical originalism is quite problematic.

For entirely sensible reasons, it is difficult to develop examples in which the procedural concern comes apart from the substantive concern cleanly. First, the fact of an undemocratic process in concept generation means that most important or interesting normative concepts will end up revealing substantive problems precisely because they are the result of a process in which the interests of some take precedence over the interests of others. Second, the extent to which we can look back and apply a critical eye to the development of our concepts depends on progressive scholarship on those concepts. That is, it is because of social justice movements, both within and outside of academia, that we now have the language to discuss concepts like sexual harassment. ${ }^{54}$ To the extent that these movements have focused on some concepts and not others, they have focused, of course, on concepts that have made a negative difference in the lives of marginalized people. ${ }^{5}$

Nevertheless, we can imagine counterfactual scenarios in which the undemocratic process of meaning-making in a society happens to create concepts that call for, and result in, justice along any number of dimensions. There might be a benevolent hermeneutic oligarchy in which the power to generate concepts is held largely by a few extraordinarily perceptive and empathetic people. If, for example, the view of women's rights advanced by

${ }^{54}$ See, e.g., Reva B. Siegel, A Short History of Sexual Harassment, in Directions IN Sexual Harassment Law 1, 8 (Catharine A. MacKinnon \& Reva B. Siegel eds., 2003).

${ }_{55}$ This is true for both practical and theoretical reasons. On the practical side, movements must respond to what hurts on the grounds. On the theoretical side, philosophers and political theorists have developed and defended the idea of non-ideal theory, which begins methodologically from the fact of injustice instead of attempting to reason down from abstract principles of justice:

Nonideal theory begins with a diagnosis of the problems and complaints of our society and investigates how to overcome these problems. Nonideal theory does not dispense with ideals but conceives of their function differently from ideal theory. In ideal theory, ideals function as standards of assessment for any society. They are not subject to testing in practice because they set standards, outside of practice, for the success of practice.

In nonideal theory, ideals embody imagined solutions to identified problems in a society. . . . Circumstances change, and new problems and complaints arise, requiring the construction of new ideals. If our ideals fail the test, we need to revise or replace them.

Elizabeth Anderson, The Imperative of Integration 6 (2010) (footnote omitted). 
John Stuart Mill ${ }^{56}$ had taken hold in the 1800 s, it might be the case that collective concepts about gender would be significantly better ${ }^{57}$ even though the theory arose out of a situation in which women did not have an equal say in theorizing about gender. In such a society, the fact that the process by which these concepts were created is undemocratic would not result in the hermeneutical gaps typical of the actual unjust world. Yet such a society is still troubling from the perspective of process. The mere fact that a person who could abuse power does not does not make a system procedurally just..$^{58}$ "Procedures that purport to bind without affording meaningful rights of participation are fundamentally illegitimate." 59

\section{Exclusionary Substance}

In addition to concerns about the undemocratic process by which language develops, the originalist should be troubled by the specter this process raises: that the substance of our concepts is undemocratic and exclusionary. If the language that expresses these concepts makes its way into law-as it almost certainly does-an uncritical originalist reading of that law does not provide a way of explaining why the language is problematic. One example of the ways in which hermeneutical injustice affects lawmaking is provided by Catharine MacKinnon's analysis of the failures of sex discrimination law. ${ }^{60}$

The legal mandate of equal treatment-which is both a systemic norm and a specific legal doctrine-becomes a matter of treating likes alike and unlikes unlike; and the sexes are defined as such by their mutual unlikeness. Put another way, gender is socially constructed as difference epistemologically; sex discrimination law bounds gender equality by difference doctrinally. A built-in tension exists between this concept of equality, which presupposes sameness, and this concept of sex, which presupposes difference. ${ }^{61}$

${ }^{56}$ John Stuart Mill, The Subjection of Women 1 (1870) ("The object of this Essay is to explain ... [t]hat the principle which regulates the existing social relations between the two sexes - the legal subordination of one sex to the other-is wrong itself, and now one of the chief hindrances to human improvement; and that it ought to be replaced by a principle of perfect equality, admitting no power or privilege on the one side, nor disability on the other.").

${ }^{57}$ I do not claim that Mill's view of gendered oppression is actually correct, but it is at least plausible for the purposes of the example.

${ }^{58}$ Indeed, part of the importance of notions of procedural justice is that they help to explain why outcomes are not the only things that matter.

${ }^{59}$ Lawrence B. Solum, Procedural Justice, 78 S. CAL. L. Rev. 181, 274 (2004).

${ }^{60}$ Catharine A. MacKinnon, Difference and Dominance: On Sex Discrimination, in Theorizing Feminisms 244, 244-45 (Sally Haslanger \& Elizabeth Hackett eds., 2006).

${ }^{61} I d$. at 244. 
On its face, sex discrimination seems simple, but how one conceives of sex discrimination will impact what seem like the correct outcomes in cases, particularly on the margins.

MacKinnon criticizes the "sameness" and "difference" approaches for failing to see sexism as a structural issue of power distribution. ${ }^{62}$ Women have been unable to theorize fully their own oppression and contribute to a better concept of sex discrimination in part because of the oppressive social situation in which they live and its ties to an undemocratic epistemic situation.

[W] hen you are powerless, you don't just speak differently. A lot, you don't speak. Your speech is not just differently articulated, it is silenced. . . . You aren't just deprived of a language with which to articulate your distinctiveness, although you are; you are deprived of a life out of which articulation might come. Not being heard is not just a function of lack of recognition, not just that no one knows how to listen to you, although it is that; it is also silence of the deep kind, the silence of being prevented from having anything to say. ${ }^{63}$

The inability to articulate a theory of sex discrimination, let alone one that will be understood and enforced by lawmakers and the courts, is a problem for women, who face sex discrimination and may have no legal recourse. But it is also a problem democratically in that law is unable, and sometimes unwilling, to respond to social experience adequately as a result of the skewed ways in which our concepts develop.

Another example may help make the stakes clear. Consider the treatment of sexual assault in the Model Penal Code (MPC). Set aside for the moment that the MPC is not itself a democratically passed statute. The MPC makes for an interesting case study in statutory interpretation both because it aims to be a model, so the drafters have, in theory, the luxury to be more precise than a legislature might, and because it carries with it commentaries of the drafters providing insight on their thought processes. The intellectual history of the development of the MPC is quite fascinating. ${ }^{64}$ There is every indication that the provisions on rape and related crimes in the MPC were crafted using what was, at the time, the best information and conceptualizations of sexual assault available. ${ }^{65}$

${ }^{62}$ See id. at $249-50$.

${ }^{63} \mathrm{Id}$. at 248.

${ }^{64}$ See generally, e.g., Deborah W. Denno, Why the Model Penal Code's Sexual Offense Provisions Should Be Pulled and Replaced, 1 Oнiо ST. J. CRiм. L. 207 (2003) (providing a history of the sexual offense provisions of the MPC and arguing for reform); Gerard E. Lynch, Revising the Model Penal Code: Keeping It Real, 1 Oнiо ST. J. CRim. L. 219 (2003) (providing a general history of the MPC and arguing for reform).

${ }^{65}$ Denno, supra note 64, at 211-13. 
The problems with the way the MPC deals with sexual assault are welldocumented. ${ }^{66}$ For example, it was drafted in a time where spousal rape was not recognized; thus, rape is defined in terms of "[a] male who has sexual intercourse with a female not his wife." ${ }^{67}$ Traditionally rape was a property offense against a husband or father. ${ }^{68}$ As rape law developed in the United States it tended to exclude women of color from its purview while simultaneously increasing scrutiny on men of color as potential assailants:

Historically, the dominant conceptualization of rape as quintessentially Black offender/white victim has left Black men subject to legal and extralegal violence. The use of rape to legitimize efforts to control and discipline the Black community is well established, and the casting of all Black men as potential threats to the sanctity of white womanhood was a familiar construct that antiracists confronted and attempted to dispel over a century ago. ${ }^{69}$

All of these moves in the law reflected dominant modes of thinking about racial and sexual politics, with the tragic outcome that rape law served largely to protect an idealized victim: a virginal white woman attacked by a man of color whom she does not know.70 "In the nineteenth century, two major goals in rape jurisprudence arose: to continue to protect white female chastity when a rape complainant embodied it; otherwise, to protect men from false accusers." 71 As Professor Crenshaw notes, "[t]he racism and sexism written into the social construction of rape are merely contemporary manifestations of rape narratives emanating from a historical period when race and sex hierarchies were more explicitly policed." 72

These narratives inform how we, as a community, think about a whole slew of interrelated concepts: race, gender, rape, criminality, the role of law, and so on. And these narratives arose out of deep strains of white supremacy and patriarchal domination, so the ways they developed predictably failed to take seriously the experiences and needs of marginalized groups. The treat-

${ }^{66}$ Carol E. Tracy et al., Rape and Sexual Assault in the Legal System, Presentation to the National Research Council of the National Academies Panel on Measuring Rape and Sexual Assault in the Bureau of Justice Statistics Household Surveys Committee on National Statistics 5-6 (2012), archived at http://perma.cc/266Z-TF8T. See generally Denno, supra note 64.

${ }^{67}$ Model Penal Code $\$ 213.1(1)$ (2001).

${ }^{68}$ Michelle J. Anderson, From Chastity Requirement to Sexuality License: Sexual Consent and a New Rape Shield Law, 70 Geo. Wash. L. Rev. 51, 61 n.72, 65 n.41 (2002).

${ }^{69}$ Kimberlé Crenshaw, Mapping the Margins: Intersectionality, Identity Politics, and Violence Against Women of Color, 43 Stan. L. Rev. 1241, 1266 (1991).

${ }^{70}$ Karin S. Portlock, Status on Trial: The Racial Ramifications of Admitting Prostitution Evidence Under State Rape Shield Legislation, 107 Colum. L. Rev. 1404, 1412-14 (2007); see also Crenshaw, supra note 69, at 1268-69.

${ }^{71}$ Anderson, supra note 68, at 69 (footnote omitted). A friendly amendment to this sentence would read: "to protect white men from false accusers."

${ }^{72}$ Crenshaw, supra note 69, at 1268. 
ment of rape and other sexual offenses in the MPC, then, offers a nice example of how well-meaning individuals, working with the best evidence available to them, will often end up advancing concepts that are substantively unjust simply because they have developed in an environment of injustice.

\section{Critical Theory as a Necessary Corrective}

The upshot of the problem of hermeneutical exclusion is not that an originalist analysis of meaning is impossible. ${ }^{73}$ Rather, the lesson for originalists - and indeed all who engage in statutory or constitutional interpretation-is that proper interpretation requires critical theory as a corrective for historical injustice. ${ }^{74}$ This is not to say that the use of critical theory is uncontroversial or easy, but that any interpretive theory that neglects to incorporate it is doomed to fail. In this Part, I explain what I mean by critical theory and argue that it is a natural fit with a sophisticated originalism.

Critical theory is an umbrella term for many different kinds of inquiry and analysis that share some common features. ${ }^{75}$ Critical theories must be "explanatory, practical, and normative." 76 Originalism already aims to be explanatory and practical: it seeks to explain what the meaning of text is, and it purports to be action-guiding for the interpreter. ${ }^{77}$ That is, it tells the interpreter how to interpret-by reference to the original public meaningand it tells the interpreter what to do with that information-enforce a statute in accord with the original public meaning where this is clear. ${ }^{78}$ Originalists do not typically take themselves to be engaged in a normative task, however. ${ }^{79}$ Rather, they are engaged primarily in the descriptive task of interpretation, uncovering a meaning that was already there with no motivation beyond getting to the best conclusion given the semantic evidence: "Mean-

${ }^{73}$ It may always be problematic, but this can fairly be said of any theory of meaning and interpretation.

${ }^{74}$ Of course, this is not the first time critical theory has been proposed as an intervention in constitutional law. See generally, e.g., Mark Tushnet, Red, White, And Blue: A Critical Analysis of Constitutional Law (1988) (providing critical analyses of grand constitutional theories, including originalism); Mark Tushnet, Critical Legal Studies and Constitutional Law: An Essay in Deconstruction, 36 Stan. L. Rev. 623 (1984) (engaging in a critical analysis of Article III). However, these interventions are not typically made in a way that suggests an originalist analysis is capable of salvation.

75 James Bohman, Critical Theory, The Stanford Encyclopedia of Philosophy (2013), http://plato.stanford.edu/archives/spr2013/entries/critical-theory, archived at http://perma.cc/A787-FEJA.

${ }_{76} I d$.

${ }^{77}$ See, e.g., Solum, Semantic, supra note 20, at 2 (laying out four theses of originalism).

${ }^{78}$ Solum helpfully distinguishes between "Pure Semantic Originalism," which is the how-to of originalism, and "Pure Normative Originalism," which is the so-what of originalism. Id. at 30 .

${ }^{79}$ Although Solum does provide a very rich account of originalism's normative justifications and components. See generally id. 
ings in the semantic sense are facts determined by the evidence. They are not courses of action adopted on the basis of normative concerns." ${ }^{80}$ Yet I have argued above that originalism's descriptive focus masks a normative focus, or is at least not normatively neutral. If it accepts historical and present power structures as given, natural, or neutral, it reinforces them through reinforcing their claim on meaning-making.

To say that some field or process is normative is to say that it aims at something - a goal, an outcome, a value, an end-but it does not say what that end is or should be. There can be many critical theories, then, which are quite at odds with each other ${ }^{81}$ In the intellectual history of law alone, critical legal studies, feminist jurisprudence, and critical race theory stand as towering examples of the diversity of critical theories.

In this Part, I try to advance a relatively minimal critical theory, which is to say that I will describe the most basic proper aims of a critical theory for constitutional and statutory interpretation. While I hope that these aims will be among the least controversial, and that they will appeal to the broadest possible base, I recognize that universal agreement is unlikely. However, I will try to pitch these normative aims in such a way as to be most appealing to current adherents of originalism by showing that they are likely already committed to the aims of such a critical theory and that these aims, if made explicit in their process of interpretation, will make for an originalism that is better both on its own terms and by external assessment.

In particular, I propose that originalism needs a critical theory oriented toward inclusive democracy. Originalists are already committed to the importance of democracy, so it should be no trouble to admit the value of attempting to include all voices in the process of meaning-making and subsequent interpretation. To accomplish this, the originalist, who is already committed to historical inquiry into meaning, must add inquiry into how that meaning came to be what it is, and whether it results from significant democratic failures, as in the case of Dred Scott..$^{82}$

Critical Theory insists ... on the mediation between theory and history through the concept of a socially efficacious reason. According to this concept, the historical past has to be understood precisely as a process of development (Bildungsprozess), whose

${ }^{80} I d$. at 36. I do want to stress at this point in the argument that Solum's careful statement is not at odds with the view I advance in this paper. It is perfectly consistent with the idea that the semantic content of a provision is set by the facts, knowable, ideally, with sufficient evidence. However, when hermeneutical injustice is added to our account of semantic meaning, we must accept that meaning itself has normative baggage. Solum seems prepared to accept some version of this already, though other originalists may be more skeptical. See, e.g., id. at 86-87 (discussing why some originalists attempt to collapse interpretation and construction together).

${ }^{81}$ See Bohman, supra note 75.

${ }^{82}$ Dred Scott v. Sandford, 60 U.S. 393 (1856). 
pathological distortion . . . can be overcome only by initiating a process of enlightenment among those affected..$^{83}$

A judge employing a critical originalist method in the Dred Scott case might thus review the history of the meaning of "citizen" and "people" in the time of the framing and conclude that the terms were meant to exclude slaves, but that these versions of the concepts were produced undemocratically in virtue of the exclusion of slaves from the creation of meaning.

An example may help to make the method, its application, and its promise more clear. Others have recently argued that the Thirteenth Amendment holds promise for progressive movements in the search to vindicate rights. ${ }^{84}$ These revisitations of the Thirteenth Amendment may provide fertile ground for imagining how a critical originalist would approach a question about the meaning of "slavery [or] involuntary servitude." ${ }^{55}$ Section 2 of the Amendment gives Congress the power to enforce this ban on slavery and involuntary servitude through legislation. The Thirteenth Amendment was, clearly enough, aimed generally at abolishing slavery in the post-Civil War period, though it was also "seen by many Republicans as securing liberty to all citizens of the United States and allowing Congress to remove badges and incidents of slavery." 86 The amendment served as the constitutional foundation for the Civil Rights Act of $1866^{87}$ and to invalidate an apprenticeship contract made for a Black minor daughter by her mother. ${ }^{88}$

As Professor Tsesis notes, the Thirteenth Amendment has an advantage over the Fourteenth Amendment with respect to reducing social injustice in that it does not have a state action requirement. ${ }^{89}$ The language of the Thir-

${ }^{83}$ Axel Honneth, Critical Theory, in The Routledge Companion to Twentieth Century Philosophy 784, 784 (2010).

${ }^{84}$ See generally, e.g., Jeffrey S. Kerr et al., A Slave by any Other Name is Still a Slave: The Tilikum Case and Application of the Thirteenth Amendment to Nonhuman Animals, 19 Animal L. 221 (2013) (arguing that the Thirteenth Amendment should be read to apply to animals living under conditions of coercion and subjugation); Alexander Tsesis, Gender Discrimination and the Thirteenth Amendment, 112 CoLum. L. Rev. 1641 (2012) (arguing that the purview of the Thirteenth Amendment should be expanded to encompass gender).

${ }^{85}$ U.S. Const. amend. XIII, § 1; see generally Marcellene E. Hearn, A Thirteenth Amendment Defense of the Violence Against Women Act, 146 U. PA. L. REv. 1097 (1998) (arguing that the Thirteenth Amendment provides authority for controversial provisions of the Violence Against Women Act); Andrew Koppelman, Forced Labor: A Thirteenth Amendment Defense of Abortion, 84 Nw. U. L. Rev. 480 (1990) (arguing that the Thirteenth Amendment provides a convincing basis for the abortion right); Joyce E. McConnell, Beyond Metaphor: Battered Women, Involuntary Servitude and the Thirteenth Amendment, 4 YAle J.L. \& Feminism 207 (1992) (analyzing the relevance of the Thirteenth Amendment's "involuntary servitude" language to situations of domestic battery).

${ }^{86}$ Michael K. Curtis, Resurrecting the Privileges or Immunities Clause and Revising the Slaughter-House Cases Without Exhuming Lochner: Individual Rights and the Fourteenth Amendment, 38 B.C. L. Rev. 1, 32 (1996).

${ }^{87}$ Tsesis, supra note 84 , at 1652.

${ }^{88}$ In re Turner, 24 F. Cas. 337, 339-40 (1867).

${ }^{89}$ Tsesis, supra note 84 , at 1643-44. It also has the virtue, unlike the Fourteenth Amendment, of being phrased in gender-neutral terms. See id. at 1643. 
teenth Amendment was enacted, in part, to secure a compromise that would exclude women's rights from the ambit of the amendment:

In part, the Senate's decision not to adopt Sumner's equality language into the Thirteenth Amendment was based on the chauvinism of congressmen like Senator Jacob Howard, . . . [who] flatly cautioned that including equality would mean that "before the law a woman would be equal to a man, a woman would be as free as a man. A wife would be equal to her husband and as free as her husband before the law."

The Thirteenth Amendment provides a good case study for our purposes in that its text in the present seems open to reasonable semantic interpretations that extend beyond remedying race-based injustices. ${ }^{91}$ The legislative history, as excerpted above, seems to indicate that the language was understood by those voting to exclude women from it, ${ }^{92}$ and an investigation into the public meaning of the terms is likely at best ambiguous. ${ }^{93} \mathrm{An}$ originalist might be able to make out the case that the original public understanding of the Amendment or its operative terms allows for its extension to gender injustice, but I suspect that it would be difficult. It is certainly the case that some activists at the time conceived of the status of women as servitude: "Feminists likened woman's degraded sociopolitical condition to the subordinated status of slaves .... Neither of them could vote, sue or be sued, own property, enter into contracts, or choose an employer." 94

A critical originalist, however, has no such difficulty in explaining how the Thirteenth Amendment could be put to the purpose of remedying gender injustices. If it is not the case that the original public meaning of the words in the Thirteenth Amendment contemplated the status of women, then we must ask why this is so. It seems likely that the understanding of the Amendment was informed by the long history of subordination based on gender and the centrality of gendered oppression in the general scheme of life. That is,

\footnotetext{
${ }^{90} \mathrm{Id}$. at 1649.

${ }^{91}$ See supra note 85.

${ }^{92}$ Tsesis, supra note 84 , at $1645-49$.

${ }^{93}$ Tsesis discusses the reception of the amendment by the public at the time, and it understandably has race as its focus:
}

People around the country understood that by ratifying the Thirteenth Amendment they were empowering Congress to pass laws against and void all the incidental violations of civil rights that had been intrinsic to slaves' lack of freedom. The framers' initial purpose in ratifying the Thirteenth Amendment had been to abolish slavery, but congressional speeches and newspaper articles from the day indicate that they expected this to only be a first step. The Fourteenth Amendment was likewise initially passed to address racially motivated injustices. It was only in the twentieth century that its statements about equal protection and due process became the sources of civil rights protections and substantive freedoms.

Id. at 1651-52 (footnote omitted).

${ }^{94} I d$. at 1662 . 
the history of excluding women from public life, denying them material benefits, and the general effect of sexist oppression contributed to the hermeneutical gap that interpretations of the Thirteenth Amendment suggest: namely, that there are aspects of women's oppression that are properly understood as involuntary servitude.

The practical effect of this interpretative move could be far-reaching. ${ }^{95}$ For example, Tsesis suggests that Congress could provide a strong "federal civil remedy for the victims of gender-motivated violence" under the amendment to replace a similar provision of the Violence Against Women Act, ${ }^{96}$ which was struck down in United States v. Morrison. ${ }^{97}$ "The statute would create a uniform, national standard to prevent any forced sex or gender-motivated violence that is closely related to one of the incidents of slavery that women suffered." 98 The critical originalist judge may move beyond the apparent meaning of a text to ask why it means what it means and, if the answer is that the meaning came about as a result of seriously undemocratic processes, she may interpret the provision to bring it in line with the goal of inclusive democracy.

While the prospect of engaging in this sort of critical originalist inquiry might seem daunting or a backdoor way for judges to impose their views on others, it is no more so either of these than an uncritical originalism. It is no more daunting because the originalist must already embark on a difficult foray into history and linguistics to make difficult decisions. The critical originalist position simply holds that they must do this with a critical eye and an aim toward truly inclusive democracy. It is no more a way to introduce particular ideology into decisions because history itself is not neutral.

Where inequalities are pervasive, the less powerful may not express their wishes even though existing values, practices, and norms inhibit their ability to live the life they desire. Where there are people who live according to values, practices, and norms they are unable to affect, social decision making is not informed, collective, and uncoerced. Where social decision making is not informed, collective, and uncoerced, social criticism plays important roles in promoting social decision making that is. In contexts of coercion and disagreement, social criticism is in part responsible for enabling those who live in the crocodile-infested water to participate in social decision making and to influence social change. ${ }^{99}$

Uncritical originalism accepts as given a language that is "not informed, collective, and uncoerced." The semantic context of our Constitu-

\footnotetext{
${ }^{95}$ See supra note 84.

${ }^{96}$ Tsesis, supra note 84 , at 1692.

97529 U.S. 598, 627 (2000).

${ }^{98}$ Tsesis, supra note 84 , at 1692 .

${ }^{99}$ Brooke Ackerly, Political Theory and Feminist Social Criticism 28 (2000).
} 
tion and other laws has been one of coercion, in need of critical intervention. Instead of accepting, without argument, meanings imposed on all, a critical originalist would carefully review the semantic context of a text, and if she determined that it arose out of a seriously undemocratic situation in a way that affected the law's legitimacy, she would note this and proceed from there.

\section{Conclusion}

In this Note, I have argued that originalism must address a serious objection that stems from a persistent feature of the semantic context of any text. Because our language, like any language, develops in unequal, and sometimes unjust, ways, an appeal to the meaning of a text and nothing more will result in reifying those inequalities. The decision to enforce the original meaning of a text without critical insight is not a neutral decision. Rather, it will often be tantamount to endorsing an oppressive history masked in common language. I propose that originalists, if they have any hope of avoiding this trap, need critical theory. A critical originalist analysis allows the originalist qua historian not only to unearth the meaning of words, but also to engage normatively with the process by which a word comes to mean one thing rather than another. 
